\title{
Implementasi Pendidikan Akhlak di Sekolah Dasar Islam Terpadu (SDIT) al-Badr Kecamatan Bangkinang Kabupaten Kampar
}

\author{
NELLY YUSRA \\ Fakultas Tarbiyah dan Keguruan Universitas Islam Negeri (UIN) Sultan Syarif \\ Kasim Riau, Email : Nellyuinz1@yahoo.com
}

\begin{abstract}
Abstrak: Pendidikan bertujuan tidak hanya merupakan kegiatan mentransfer ilmu pengetahuan kepada peserta didik, tetapi juga mentransfer nilai-nilai akhlak dan nilai-nilai kemanusian. Maka, untuk mencari informasi mengenai faktor-faktor yang mendukung dan menghambat implementasi pendidikan akhlak, penelitian terkait pendidikan akhlak ini perlu dilakukan. Penelitian ini lakukan di SDIT al-Badr Kabupaten Kampar yang bertujuan untuk mengetahui bagaimana implemetasi pendidikan akhlak dan untuk mengetahui faktor-faktor yang mendukung dan menghambat implementasi pendidikan akhlak tersebut. Hasil penelitian ini menyebutkan bahwa faktor-faktor yang mendukung keberhasilan sekolah dalam mengimplementasikan pendidikan akhlak adalah komitmen yang kuat dari pihak sekolah, komitmen yang kuat dari yayasan dalam mewujudkan generasi yang berakhlak mulia, adanya petunjuk teknis yang jelas untuk pelaksanaan bimbingan akhlak, serta hubungan yang baik sesama warga sekolah dan lingkungan sekolah, dan majlis guru yayasan alBadr. Adapun faktor penghambat yaitu kurangnya kerjasama antara orang tua dengan pihak sekolah dalam mewujudkan generasi Islami, namun hal ini dapat dijembatani dengan diadakannya pertemuan rutin orang tua dan pihak sekolah untuk menyatukan visi dan misi dalam mewujudkan pengembangan akhlak mulia diantara para siswa.
\end{abstract}

Kata kunci: Pendidikan akhlak, faktor pendukung, faktor penghambat

\section{PENDAHULUAN}

Pada dasarnya pendidikan adalah untuk mengembangkan potensi individu sebagai manusia sehingga dapat hidup secara optimal, baik sebagai pribadi maupun sebagai bagian dari masyarakat serta memiliki nilai-nilai moral dan sosial sebagai pedoman hidup (Sudjana, 1991: 2). Dengan demikian pendidikan memegang peran penting dalam menentukan hitam putihnya manusia, dan akhlak menjadi standar utama kualitas manusia. Artinya, baik buruknya akhlak merupakan salah satu indikator berhasil atau tidaknya pendidikan.

Pendidikan bukan hanya bertujuan membentuk manusia yang cerdas otaknya dan terampil dalam melaksanakan tugas, namun diharapkan dapat menghasilkan manusia yang berakhlak mulia, sehingga menghasilkan 
warga negara yang excellent. Oleh karena itu pendidikan tidak sematamata mentransfer ilmu pengetahuan kepada peserta didik, tetapi juga mentransfer nilai-nilai akhlak dan nilainilai kemanusian yang bersifat universal. Dengan tranfer akhlak yang bersifat universal, diharapkan peserta didik dapat menghargai kehidupan orang lain tercermin dalam tingkah laku serta aktualisasi diri, semenjak usia SD hingga kelak dewasa menjadi warga negara yang baik (good citizen).

Namun pada kenyataannya manusia Indonesia (khususnya anakanak usia sekolah) saat ini, kurang memperhatikan nilai akhlak yang tercermin dari perilaku tidak menghormati nilai-nilai kemanusiaan seperti terjadi tawuran remaja, kurang menghormati orang tua, kurang menghormati guru, dan terhadap figurfigur yang berwenang, kurang mentaati norma-norma keluarga, hidup tidak di siplin, meningkatnya kertidakjujuran, seperti suka bolos, nyontek, dan suka mencuri, meningkatnya kelompok teman sebaya yang bersifat kejam dan bengis, munculnya kejahatan yang memiliki sikap fanatik dan penuh kebencian, berbahasa tidak sopan, merosotnya etika kerja, meningkatnya sifat-sifat mementingkan diri sendiri dan kurangnya rasa tanggung jawab sebagai warga negara, timbulnya gelombang perilaku yang merusak diri sendiri seperti perilaku seksual premature, penyalahgunaan mirasantika/narkoba, perilaku bunuh diri, timbulnya ketidaktahuan sopan santun termasuk mengabaikan pengetahuan moral sebagai dasar hidup, seperti adanya kecenderungan untuk memeras tidak menghormati peraturanperaturan, dan perilaku yang membahayakan terhadap diri sendiri atau orang lain.
Terlebih lagi pada masa globalisasi manusia Indonesia cendrung berprilaku keras, cepat, akseleratif dalam menyelesaikan sesuatu, dan budaya instan. Manusia dipaksa hidup seperti robot, selalu berada pada persaingan tinggi (konflik) dengan sesama, hidup bagaikan roda yang berputar cepat, yang membuat manusia mengalami disorientasi, meninggalkan normanorma universal, menggunakan konsep Machiavelli (menghalalkan segala cara), mementingkan diri sendiri, dan tidak memiliki moral yang baik, tidak menghargai, mengasihi dan mencintai sesama (Nashir, 2007: 10).

Dengan diberikannya pendidikan akhlak kepada anak SD diharapkan dapat merubah perilaku anak, sehingga peserta didik jika sudah dewasa lebih bertanggung jawab dan menghargai sesama dan mampu menghadapi tantangan zaman yang cepat dan berubah. Di sinilah pentingnya nilainilai akhlak yang berfungsi sebagai media transfarmasi manusia Indonesia agar lebih baik, memiliki keunggulan dan kecerdasan diberbagai bidang, baik kecerdasan emosional, kecerdasan sosial, kecerdasan spritual, kecerdasan kinestika, kecerdasan logis, musikal, dan linguistik (Istanto, 2007: 1).

Dalam Islam, akhlak merupakan tema sentral, sebagai tujuan pendidikan Islam dan akhlak dijadikan oleh Allah sebagai ukuran keimanan seseorang. Artinya kesempurnaan iman seseorang dilihat dari kebaikan akhlaknya. Hal ini berdasarkan penjelasan Rosulullah dalam sebuah hadist :

"Seorang mukmin yang sempurna imannya adalah yang terbaik akhlaknya" (HR. Abu Daud dan Tirmizi).

Menurut Abuddin Nata, akhlak adalah perbuatan yang dilakukan dengan mendalam dan tanpa pemikiran, namun perbuatan itu telah mendarah daging dan melekat dalam jiwa, 
sehingga saat melakukan perbuatan tidak lagi memerlukan pertimbangan dan pemikiran (Nata, 1997: 5) .

Oleh karena itu orang tua, guru, dan siapapun yang bertanggung jawab terhadap pendidikan, harus membiasakan dan melatih anak berakhlak mulia, sesuai dengan jiwa zaman yang sedang dihadapi saat ini, agar kelak peserta didik (anak-anak SD) bagaikan anak panah lepas dari busurnya menentang, mengatasi permasalahannya sendiri, namun memiliki keunggulan akhlak yang baik dan luhur.

Untuk menumbuhkan dan mengembangkan akhlak yang mulia, diperlukan lembaga-lembaga pendidikan yang menjadikan pembinaan akhlak sebagai isu sentral, dan keberadaannya merupakan salah satu sarana untuk membangun kebaikan individu, masyarakat dan peradaban manusia. Dan perlu diingat dalam pembinaan pendidikan akhlak tersebut perlu dirancang dengan baik dengan memperhatikan peluang dan tantangan yang muncul (Daulay, 2004: 216).

Salah satu lembaga pendidikan yang mengedepankan pendidikan akhlak adalah SDIT al-Badr yang berada di Kabupaten Kampar. Lembaga pendidikan ini telah berdiri pada tahun 2002. Perkembangannya boleh dikatakan pesat, dan menarik minat masyarakat. Peminatnya semakin hari semakin banyak, bahkan tidak tertampung dan terpaksa dibatasi, karena keterbatasan sarana dan prasarana yang ada di sekolah ini. Pada awalnya siswa SDIT al-Badr hanya lima orang siswa pada tahun pertama (2002), dan selanjutnya berkembang menjadi 360 siswa pada tahun 2013.

Pendidikan akhlak di SDIT alBadar dapat dikatakan bagus terlihat dari beberapa fenomena positip, di lembaga ini antara lain, ketika memasuki lembaga pendidikan ini akan ditemukan anak-anak yang disiplin, datang ke sekolah sebelum waktu masuk belajar, mereka membersihkan lingkungan sekolah, mengutip sampahsampah yang masih tersisa, kemudian sambil menunggu waktu belajar dimulai di tangan-tangan mereka terbuka lembaran-lembaran kitab suci al-Quran atau buku-buku bacaan lainnya. Setelah masuk jam pelajaran mereka masuk secara teratur, dengan memberikan penghormatan kepada guru dan mengikuti pelajaran dengan tekun dan tenang.

Keta'atan dan kepatuhan kepada guru sepertinya begitu tertanam dan mendarah daging pada diri mereka. Ketika jam istirahat secara teratur dan berdisiplin mereka berbaris, antrian menunggu giliran mereka berbelanja di koperasi atau di kantin sekolah. Tidak ada yang berdesak-desakan semua menunggu dengan sabar giliran mereka. Selanjutnya secara bergantian mereka melakukan sholat dhuha sesuai dengan jadwal dari sekolah. Pada waktu zuhur, para siswa sholat berjemaah di mesjid dengan tenang, berzikir dan membaca al-Quran, lalu dilanjutkan dengan makan siang secara berkelompok dengan teratur. Kemudian masuk belajar, sholat asar berjema'ah dan pulang dengan teratur, dengan penuh penghormatan kepada guru-gurunya.

Ada beberapa hal yang menarik yang pernah diungkapkan oleh orang siswa mengenai akhlak anaknya setelah di sekolahkan di SDIT al-Badr. Salah seorang wali murid mengungkapkan: "Anak saya sekarang sudah melaksanakan sholat tepat waktu, rajin membaca al-Quran, taat kepada orang tua, bangga berbusana muslimah, bahkan selalu mengingatkan saya agar senantiasa menjaga aurat di manapun, saya terkadang jadi malu bercampur kagum. Hal yang senada juga diungkapkan oleh wali murid yang lain: 
"Anak saya sudah banyak hafal Quran, berdisiplin, jujur dan patuh pada orang tua dan guru".

Pernyataan-pernyataan wali murid tersebut tidak berlebihan, karena berdasar observasi peneliti, kondisi tersebut memang ditemukan di sekolah ini. Bahkan dalam wisuda siswa tamatan tahun 2013, ada siswa SDIT al-Badr ini yang telah menghafal al-Quran 5 juz, dan cukup diperhitungkan dibeberapa oliempade ilmu pengetahuan antar Sekolah Dasar ditingkat Kabupaten.

Suasana tenang dan menyejukkan di lembaga pendidikan ini menggambarkan keindahan akhlak para siswanya, yang merupakan hasil pendidikan dari para pendidiknya.

Dari latar belakang di atas penulis tertarik untuk mengadakan penelitian lebih lanjut di SDIT al-Badr ini. Ada beberapa permasalahan yang akan dikaji secara mendasar dalam penelitian ini. Permasalahpermasalahan tersebut antara lain: (1) Bagaimana implementasi Pendidikan Akhlak di SDIT al-Badr Kecamatan Bangkinang Kabupaten Kampar?; dan (2) Apakah faktor-faktor yang mendukung dan menghambat implementasi pendidikan Akhlak di SDIT al-Badr Kecamatan Bangkinang Kabupaten Kampar?

Peneltian ini bertujuan untuk mengetahui bagaimana implemetasi pendidikan akhlak di SDIT al-Badr Kabupaten Kampar dan untuk mengetahui faktor-faktor yang mendukung dan menghambat implementasi pendidikan akhlak di lembaga pendidikan al-Badr Kabupaten Kampar. Adapun kegunaan penelitian ini diharapkan dapat mencari informasi mengenai cara implementasi pendidikan akhlak di SDIT al-Badr Kabupaten Kampar, mencari informasi mengenai faktor-faktor yang mendukung dan menghambat implementasi pendidikan akhlak di lembaga Pendidikan al-badr Kabupaten Kampar; mengambil format yang baik dari implementasi pendidikan akhlak di SDIT al-Badr Kabupaten Kampar, agar dapat dijadikan acuan oleh berbagai pihak yang membutuhkan dan untuk menambah khazanah ilmu pengetahuan di bidang penelitian.

\section{METODE}

Penelitian dilaksanakan di lembaga pendidikan SDIT al-Badr Kabupaten Kampar, jalan Jendral Sudirman RT/RW 01/18 Kelurahan Langgini Kecamatan Bangkinang Kabupaten Kampar. Penelitian ini dilaksanakan tahun 2013

Penelitian ini menggunakan metode informan. Informan adalah individu yang diharapkan dapat menjadi mitra peneliti untuk memudahkan penelitian.

Adapun Objek penelitian ini adalah siswa-siswi Sekolah Dasar Islam Terpadu (SDIT) al-Badr, dengan maksud untuk mengetahui dan menggungkap sejauh mana mereka mengimplementasikan akhlak sehari-hari dalam bergaul di sekolah. Sedangkan subjek penelitian adalah kepala sekolah SDIT al-Badr, waka Kesiswaan, para guru, siswa-siswi dan orang Tua siswa.

Untuk mendapatkan data yang diperlukan dalam penelitian ini, peneliti berusaha unuk mendapatkan data yang valid dan bisa dipertanggung jawabkan dengan menggunakan metode sebagai berikut: Pertama, Interview/ Wawancara. Wawancara adalah percakapan dengan maksud tertentu. Prcakapan ini dilakukan oleh dua pihak, yaitu pewawancara (interviewer) yang mengajukan pertanyaan) dan terwawancara (interviewee) yang memberikan jawaban atas pertanyaan. Cara jenis wawancara menurut Paton 
yangdikutip oleh Moleong ada tiga yaitu: (a) Wawancara Pembicaraan informal. Jenis wawancara ini pertanyaan yang diajukan sangat bergantung pada pihak pewawancara itu sendiri. Hubungan pewawancara adalah suasana biasa, wajar sedangkan pertanyaan dan jawabannya berjalan seperti biasa dalam kehidupan sehari-hari; (b) Pendekaan menggunakan petunjuk umum wawancara. Jenis wawancara ini mengharuskan pewawancara membuat petunjuk kerangka dan garis-garis pokok yang dirumuskan tidak perlu ditanyakan berurutan; dan (c) Wawancara baku terbuka. Jenis wawancara ini adalah wawancara yang menggunakan seperangkat pertanyaan baku. Uruan pertanyaan, kata-katanya, dan cara penyajiannya pun sama untuk setiap responden. Keluwesan mengadakan pertanyaan pendalaman terbatas, hal ini tergantung kepada situasi wawancara dan kecakapan pewawancara. Pada penelitian ini penulis menggunakan ketiga model wawancara di atas.

Kedua, Observasi. Observasi (observation) atau pengamatan merupakan suatu teknik atau cara mengumpulkan data dengan jalan mengadakan pengamatan terhadap kegiatan yang sedang berlangsung (Sukmadinata, 2007: 220). Metode ini peneliti gunakan untuk mendapatkan data yang berhubungan dengan implementasi pendidikan akhlak di SDIT al-badr. Dalam pelaksanaan observasi dibedakan menjadi tiga, yaitu: (a) Observasi langsung, adalah pengamatan langsung terhadap objek yang diteliti; (b) Obsevasi tidak langsung, adalah pengamatan yang dilakukan pada suatu objek melalui perantara suatu alat atau cara, baik dilakukan dalam situasi sebenarnya atau tiruan; dan (c) Observasi partisifatif, adalah pengamatan yang dilakukan dengan cara ikut ambil bagian aau melibatkan langsung dengan objek yang diteliti. Ketiga model observasi di atas peneliti gunakan dalam pengumpulan data pada penelitian ini.

Ketiga, Dokumentasi. Dokumentasi adalah setiap bahan tertulis atau film. Dokumen digunakan dalam penelitian sebagai sumber data karena dalam banyak hal dokumen sebagai sumber data dimanfaatkan untuk menguji, menafsirkan bahkan meramalkan. Metode ini peneliti gunakan untuk memperoleh informasi tambahan yang telah penelti peroleh melalui observasi, wawancara maupun catatan lapangan yang telah peneliti lakukan.

Sedangkan metode analisis data dalam penelitian ini adalah metode deskriftif kualitatif. Analisis data kualitatif terdiri dari tiga alur kegiatan yang terjadi secara bersamaan yaitu reduksi data, penyajian data, dan penarikan kesimpulan atau verifikasi. Miles menjelaskan maksud langkahlangkah tersebut yaitu: (1) Reduksi data. Reduksi data diartikan sebagai proses pemilihan, pemusatan perhatian pada penyederhanaan, pengabstrakan, dan transformasi data kasar yang muncul dari catatan-catatan tertulis di lapangan. Reduksi data dilakukan selama penelitian berlangsung, setelah penelti di lapangan, sampai laporan tersusun. Reduksi data adalah sebuah bentuk analisis yang menajamkan, menggolongkan,mengarahkan, membuang data yang tidak perlu, dan mengorganisasi data sehingga kesimpulan final dapat diambil dan diverifikasi. Data kualitatif dapat disederhanakan dan ditransformasikan dengan berbagai cara: seleksi, ringkasan, penggolongan, dan bahkan ke dalam angka-angka; (2) Penyajian data. Penyajian data merupakan alur kedua dalam kegiatan analisis data. Data dan informasi yang telah diperoleh di 
lapangan dimasukkan kedalam suatu matriks. Penyajiannya dapat meliputi berbagai jenis matrik, grafik, jaringan dan bagan; dan (3) Verifikasi dan Kesimpulan. Setelah matrik terisi, maka kesimpulan awal dapat dilakukan. Sekumpulan informasi yang tersusun memungkinkan adanya penarikan kesimpulan dan pengambilan tindakan. Kesimpulan juga diverifikasi selama penelitian berlangsung.

Jadi analisis data yang peneliti gunakan adalah upaya mencari dan menata secara sistematis catatan observasi, wawancara, catatan lapangan dan lainnya untuk meningkatkan pemahaman peneliti tentang masalah yang diteliti. Dengan demikian metode analisis data merupakan proses mengatur data kemudian mengorganisasikannya kedalam satu pola, katagori dan suatu uraian, yang dimulai dengan menela'ah seluruh data yang dikumpulkan melalui observasi, interview mapun dokumentasi, baru kemudian ditarik kesimpulan dengan metode deskriftif.

\section{HASIL}

Adapun cara implementasi pendidikan akhlak di SDIT al-Badr adalah dilaksanakan program Pembinaan tahfiz al-Quran secara rutin, latihan Wudhu, Sholat, Zikir dan Doa, bimbingan Adab di Majlis belajar, bimbingan pada jam Istirahat, bimbingan Adab Makan dan Minum, dan bimbingan adab pulang sekolah.

\section{Dilaksanakan program Pembinaan tahfiz al-Quran secara rutin}

Berdasarkan wawancara peneliti dengan Kepala sekolah SDIT alBadr, beliau mengungkapkan bahwa strategi utama keberhasilan pembinaan akhlak di SDIT al-badr yaitu membiasakan anak akrab dengan alQuran, mulai dari membaca al-quran dengan tahsinnya, menghafal dan mengamalkannya dalam kehidupan sehari-hari. Karena Rosulullah Saw telah menjamin dalam sebuah hadisnya : "Bacalah oleh kamu al-Quran karena ia akan menjadi cahaya (pembimbing) bagimu di dunia dan bekal yang berharga bagimu diakhirat kelak". (HR. Tabrani). Dalam pelaksanaan bimbingan tahfiz al-Quran seorang guru bertanggung jawab terhadap enam orang siswa. Guru yang telah ditunjuk, membimbing anak dalam membaca, menghafal al-Quran, memberikan penilaian terhadap akhlak anak-anak dalam mempelajari al-Quran sekaligus memberikan reward terhadap anak yang ahklaknya baik dalam proses belajar al-quran. Waktu yang disediakan untuk mata pelajaran tahfiz al-quran 5 hari belajar, yaitu senin, selasa,rabu, kamis, dan jumat. Setiap kali pertemuan sebanyak 2 mapel, 1 jam 10 menit. Guru yang telah ditunjuk minimal telah hafal 6 juz al-Quran, dan berakhlak mulia. Adapun moto guru di SDIT al-badr adalah semua guru adalah guru alQuran, semua guru bertanggung jawab untuk membentuk lingkungan yang qurani.

Berdasarkan observasi yang peneliti lakukan, anak mengikuti dengan tekun proses pembelajaran dan penghafalan al-Quran, guru membimbing dengan penuh kasih sayang, bacaan anak dengan benar, dan mendengarkan hafalan para siswa dengan baik. Terkadang guru memberikan hadiah langsung kepada siswa yang ada dibawa bimbingannya sebagai motivasi untuk bersemangat menghafal al-Quran. Salah seorang guru bernama Meri Jeni, SE.i di sekolah ini mengungkapkan "Dalam proses pembinaan hafalan al-Quran, kami memberikan penilaian langsung terhadap akhlak siswa, seperti 
kesungguhannya, kedisiplinannya, sekaligus memberikan penilaian terhadap hasil hafalan al-Qurannya, sementara bagi siswa yang baik dan berprestasi kami berikan hadiah langsung, berupa pujian, atau hadiah." Pihak sekolah memberikan hadiah berupa uang tunai, kepada siswa yang berhasil mengafal al-Quran setiap semester, dengan perincian 1 juz 100.000, 2 juz 200.000 demikian seterus. Pada wisuda anak SDIT al-Badr tahun 2013, beberapa orang anak telah dapat menamatkan hafalannya sebanyak 5 juz. Dan satu hal yang membanggakan lagi bahwa pada tahun 2013 ini SDIT al-Badr membuka kelas khusus Tahfiz al-Quran untuk tingkat SD, dengan jumlah murid 15 orang siswa.

Berdasarkan observasi lebih lanjut, peneliti melihat bahwa dalam mengimplementasikan hafalan alQuran, para guru telah memberikan contoh teladan, bahwa mereka sudah menghafal terlebih dahulu al-Quran dan membimbing anak dengan akhlak alQuran, sesuai dengan motto sekolah ini "setiap guru adalah guru al-Quran."

Karena setiap guru adalah guru alQuran, maka semua guru dalam mengajarkan materi pelajaran harus menekankan dan memperhatikan pendidikan akhlak anak, tanpa terkecuali. Disamping hal di atas, untuk mengimplementasikan pendidikan akhlak, anak-anak diwajibkan menghafal hadist arbain secara bertingkat, dan kitab matan jurumiah.

\section{Latihan Wudhu, Sholat, Zikir dan Doa}

Di SDIT al-Badr pembinaan akhlak kepada Allah swt., dilaksanakan dengan membiasakan anak melaksanakan sholat setiap hari pada waktunya yaitu sholat zuhur dan asar. Seorang guru di sekolah ini mengungkapkan bahwa setiap tiba waktu sholat zuhur dan asar khususnya, kami membimbing anak mulai dari pelaksanaan wuduk sampai pelaksanaan sholat dan zikir serta doa yang dibaca sesudah sholat. Bagi siswa yang dinilai sudah bagus pelaksanaan sholatnya diperbolehkan sholat di mesjid, sedangkan bagi siswa yang belum, dibina dikelas terlebih dahulu. Sholat di sini tidak hanya sholat wajib, tetapi juga pembiasaan sholat dhuha. Namun untuk pelaksanaan sholat Dhuha dipergilirkan harinya untuk masingmasing lokal dan dilaksanakan di mesjid. Untuk sholat dhuha dibiasakan terutama bagi kelas tiga ke atas. Pembiasaan sholat ini bertujuan agar anak dekat dengan Allah SWT, dengan demikian akan mencegah diri mereka terhadap perbuatan keji dan mungkar sebagaimana yang menjadi tujuan pendidikan sholat itu sendiri, disamping diharapkan anak akan terbiasa dengan akhlak yang mulia. Pernyataan ini didukung oleh observasi yang peneliti laksanakan. Peneliti melihat langsung para guru membimbing siswa dengan penuh tanggung jawab dalam pelaksanaan wuduk hingga sholat. Hal ini juga didukung oleh pernyataan salah seorang wali murid, berkata: "anak saya sekarang sudah sholat tepat waktu, berdisiplin, hormat kepada orang tua, berkarekter baik, berbeda dengan sebelum masuk ke sekolah ini". Pernyataan orang tua siswa ini menunjukkan keberhasilan sekolah dalam membiasakan anak dalam berhubungan baik dengan Allah yang akan beimplikasi kepada hubungan baik kepada sesama manusia. Adapan pedoman pelaksanaan bimbingan akhlak pada pembiasaan sholat ini di SDIT al-badr adalah sebagai berikut: (a) Memperhatikan contoh cara wudhu' yang di tampilkan guru; (b) Melakukan wudhu' dengan perlahan untuk memastikan semua pelaksanaan rukun 
dan syarat syah wudhu'; (c) Membaca do'a dan niat ketika sebelum dan sesudah secara jahar dan merenungi kesalahan agar diampuni oleh Allah; (d) Menghafal semua bacaan sholat, zikir dan do'a sekaligus dengan terjemahan dan pemahaman yang benar; (e) Melakukan gerakan sholat sesuai dengan sifat-sifat sholat nabi; (f) Menyusun shaf sholat menurut usroh/ kelompok masing-masing atau memenuhi shaf yang tedepan; (g) Mengimami jama'ah dengan membaca hapalan ayat-ayat al qur'an minimal 1 (satu) halaman serakaat; (h) Membaca semua bacaan sholat, zikir dan do'a dengan suara halus, khusu', penuh pemahaman dan berulang-ulang sesaui dengan ketentuan; dan (i)Menyediakan dan merapikan kembali sajadah dengan baik tenang.

\section{Bimbingan Adab di Majlis belajar}

Bimbingan anak di majlis belajar bertujuan agar anak dapat belajar dengan baik dan tenang. Apabila dalam belajar anak telah menerapkan akhlak menuntut ilmu, maka ilmu tersebut akan diperoleh dan bermanfaat bagi kehidupan mereka sehari-hari. Salah seorang guru menyatakan sebelum anak-anak masuk ke dalam kelas, mereka berbaris dengan rapi, dan masuk ke kelas dengan tenang. Sebelum pelajaran dimulai anak-anak dibiasakan berdoa, duduk dengan rapi dan tenang. Apabila kondisi tersebut belum terwujud pelajaran tidak akan di mulai. Pernyataan ini didukung oleh hasil observasi peneliti terhadap proses pembelajaran di beberapa kelas SDIT alBadr. Murid- murid sepertinya menikmati belajar, mereka bersungguhsungguh mendengar penjelasan guru dan melakukan tugas-tugas yang diperintahkan guru dalam suasana tenang. Para siswa sepertinya sangat menghormati guru-guru mereka. Hal ini boleh jadi disebabkan guru-guru tersebut pantas dijadikan sebagai contoh teladan bagi siswa. Perkataan lemah lembut, penuh kasih sayang, prilaku yang baik dalam mendidik siswa, sudah menjadi fenomena biasa di sekolah ini. Ada suatu hal yang menarik peneliti di sekolah ini, yaitu terciptanya suasana tenang, saling hormat menghormati, dan menyejukkan. Hal ini juga dinyatakan oleh salah seorang wali murid, di sekolah ini hampir tidak terdengar keributan, yang ada suasana tenang dan damai. Adapun pedoman pelaksanaannnya sebagai berikut : (a) Memasuki ruangan majlis dengan tenang dan tidak tergesa-gesa; (b) Duduk dengan tenang, rapi dan posisi duduk yang tepat; (c) Memulai dengan membaca Hamdalah, Shalawat dan Do'a; (d) Mempersiapkan, membuka dan membaca buku pelajaran walaupun guru belum memasuki ruangan majlis belajar; (e) Mendengar dengan tenang dan penuh perhatian terhadap penjelasan dan keterangan guru; (f) Melaksanakan tugas sekolah dengan penuh serius, hati-hati dan rapi; (g) Menghapal semua pelajran sesuai dengan ketentuan dan kesanggupan masing-masing; (h) Tidak keluar dari ruangan majlis selama belajar, kecuali diizinkan guru dan bergilir, tidak berbondong-bondong; (i) Menanyakan sesuatu yang tidak dimengerti atau tidak tahu dengan cara menunjuk tangan tanpa ribut, dan mulai bicara ketika dipersilahkan oleh guru; (j) Merapikan semua buku, alat tulis, meja dan kursi, cara duduk selama proses belajar; (k) Menutup majlis belajar dengan membaca Hamdalah, Shalawat dan do'a; dan (l) Keluar dari ruangan majlis dengan sopan, teratur, tenang dan tidak tergesa-gesa apalagi berlarilari. 


\section{Bimbingan pada jam Istirahat}

Pada jam istirahat, anak-anak dibimbing guru secara teratur keluar dari kelas. Sebelum anak-anak menuju kantin sekolah, mereka berbaris secara teratur dan berangkat menuju kantin dengan tenang. Salah seorang guru menyatakan setiap jam istirahat kami membimbing siswa berbaris secara teratur, agar berdisiplin menuju kantin, hal ini dilakukan supaya siswa biasa berbudaya antri, berdisiplin dan jujur dalam berbelanja. Pernyataan ini didukung oleh observasi yang peneliti laksanakan beberapa kali di sekolah ini. Guru, terutama wali kelas dan sekretaris, membimbing anak-anak berbudaya antri dan berdisiplin menuju kantin. Dan ada hal yang menarik di sekolah ini yaitu kantin wanita dibedakan dengan kantin laki-laki. Hal ini salah satu cara untuk mendidik anakanak untuk tidak bercampur baur dengan lawan jenis.

Adapun pelaksanaannya secara rinci yaitu: (a) Keluar dari ruangan majlis dengan tenang, sopan dan teratur; (b) Berbelanja dengan jujur dan tenang dan tertib; (c) Membeli barangbarang, makanan dan minuman yang halal lagi baik; (d) Membawa belanjaan ketempat usroh/ kelompok dan tidak mencicipinya diwaktu berjalan; (e) Membuka dan menyusun sepatu sebelum duduk bersama; (f) Berkumpul dengan membentuk lingkaran, lutut beradu dengan lutut teman, pada tempat usroh/ kelompoknya masingmasing setelah berbelanja; (g) Makan dan minum dalam keadaan duduk dan menggunakan tangan kanan yang bersih; (h) Membaca do'a akan makan dengan penuh khusu' dengan suara halus; (i) Membiasa memberi makanan dan minuman kepada teman yang tidak ada belanjaan; (j) Tidak meminta-minta dan mengambil-ambil makanan dan minuman yang dimiliki teman; (k) Berbicara dan bercerita dengan suara yang rendah dan yang baik-baik; (l) Membaca do'a dengan penuh pemahaman dan dengan hati yang tunduk kepada Allah; (m) Mengumpulkan dan mengutip sampah tanpa menyisakan walaupun hanya berbentuk pasir dan memasukkannya kedalam tempat sampah; (n) Memakai sepatu dengan rapi dengan mendahulukan sebelah kanan; (o) Merapikan kembali tikar tempat berkumpul dan meletakkannya pada tempat penyimpanannya; dan (p) Memasuki ruangan majlis belajar dengan penuh konsentrasi dan tenang 5 (lima) menit sebelum bel masuk berbunyi.

\section{Bimbingan Adab Makan dan Minum}

Pada jam istirahat makan siang, anak-anak SDIT al-badr, dibimbing oleh guru, untuk makan siang. Seorang guru menyatakan bahwa "pada jam makan siang masing-masing siswa berkumpul dalam kelompoknya sesuai dengan urutan kelas, dan dipisahkan antara murid laki-laki dan wanita. Pada kesempatan ini para guru mengajar adab makan yang benar dalam Islam. Pernyataan ini sesuai dengan hasil observasi peneliti di SDIT al-Badr, bahwa terlihat para siswa secara teratur di bawah bimbingan guru, menikmati makan siang. Suasana kekeluargaan begitu kental terlihat, antara murid dan guru. Adapun pelaksanaannya yaitu: (a) Menyuci kedua tangan dengan baik dan sempurna; (b) Berkumpul menurut usroh/ kelompoknya masing-masing dengan tenang dan tertib; (c) Membaca do'a dengan penuh harap keberkahan makan dan minum dari Allah; (d) Melakukan aktivitas makan dan minum dengan tangan kanan dan dalam keadaan duduk dengan baik dan sopan; 
(e) Minum sedikit air putih sebelum makan; (f) Menyuap makanan dan mengambil minuman dengan baik agar tidak terbuang kelantai/ meja; (g) Mengunyah makanan sampai halus sebelum ditelan; (h) Tidak berbicara dan berbincang-bincang sewaktu mengunyah dan minum; (i) Senantiasa menggunakan tangan kanan selama makan dan minum; (j) Beristirahat sebentar dalam keadaan duduk sesudah makan dan minum; (k) Berbicara dan berbincang-bincang tentang yang baikbaik dengan suara sopan; (l) Membaca do'a sesudah makan dan minum dengan khusu' serta berharap bebas dari azab neraka; (m) Merapikan dan membersihkan semua peralatan dan tempat makan minum; dan (n) Memasuki ruangan belajar dengan tertib dan tenang.

\section{Bimbingan Adab Pulang Sekolah}

Sebelum pulang ke rumah, muridmurid SDIT al-badr, dibimbing guru, untuk mempraktekkan adab pulang sekolah. Dengan pembiasaan ini diharapkan anak terbiasa berdisiplin dan teratur. Salah sorang guru menyatakan bahwa, sebelum pulang murid-murid dibimbing berdoa dan mengucapkan salam dan keluar dari kelas dengan tenang. Anak-anak yang dianggap akhlaknya paling baik, diperbolehkan terlebih dahulu pulang. Adapun pelaksanaannya yaitu: (a) Keluar dari ruangan majlis belajar dengan tenang dan tertib; (b) Mengucapkan salam kepada guru dan teman ketika berpisah; (c) Berjabat tangan sebelum berpisah, laki-laki sesama laki-laki, perempuan sesama perempuan; (d) Menunggu jemputan dalam keadaan duduk dengan teratur didalam pekarangan sekolah dan di tempat duduk yang disediakan; (e) Membaca buku pelajaran atau mengulang hapalan al qur'an dan hadits selama menunggu jemputan; (f) Tetap memakai seragam sekolah dengan rapi dan bersih; (g) Menaiki kenderaan dengan hati-hati dan membaca do'a dengan penuh harap keselamatan dari Allah; (h) Tidak singgah kerumah dan tempat apaun selama menuju ruamah, kecuali sepengetahuan guru dan atau orang tua; (i) Sesampai di rumah membaca do'a dan mengucapkan salam dengan penuh rindu kepada keselamatan orang tua dan keluarga; (j) Bersalaman denga semua anggota keluarga yang berjumpa sewaktu kembali kerumah; dan (k) Meletakkan semua pelengkapan dan peralatan dan seragam sekolah pada tempatnya dengan rapi.

Di samping pembinaan akhlak pribadi murid-murid SDIT al-Badr, sebagaimana telah dijelaskan, mereka juga dibiasakan berakhlak baik pada lingkungan sekolah. Berdasarkan observasi peneliti, SDIT al-Badr adalah lingkungan yang bersih dan Islami. Lingkungan sekolah seperti lokal, mesjid, kantin, perpustakaan, dan wc, bersih, indah dan menyejukkan hati. Berdasarkan wawancara peneliti dengan salah seorang guru, sekaligus pengurus yayasan, ia menjelaskan, pendidikan kebersihan, terhadap diri pribadi dan lingkungan, terutama lingkungan sekolah sudah ditanamkan sejak dini kepada para siswa, dengan guru sebagai contoh teladannya. Prilaku bersih setiap hari ditekankan dan dibiasakan kepada seluruh siswa, sehingga pada akhirnya menjadi sebuah budaya dalam kehidupan mereka. Adapun standar minimal akhlak terhadap lingkungan yaitu: (1) Akhlak di Lokal belajar meliputi: (a) Membersihkan dan merapikan meja, kursi, papan tulis, lantai, jendela, dan semua peralatan belajar sebelum dimulai kegiatan belajar; (b) Tidak menulis, mencoret-coret dan merusak 
bangunan dan peralatan sekolah; (c) Tidak mengotori lokal dengan kertas, sampah meruncing pensil, bungkusbungkus dan lainnya; dan (d) Memelihara poster, daftar, alat peraga dan lainnya yang di pampangkan di dinding lokal; (2) Akhlak di lingkungan kantor meliputi: (a) Memasuki kantor apabila salam telah dijawab oleh guru yang ada didalam kantor; dan (b) Mengambil dan menggunakan peralatan, perlengkapan yang ada didalam kantor, atas sepengetahuan guru; (3) Akhlak di lingkungan pustaka, meliputi: (a) Masuk ke dalam pustaka bersama guru mata pelajarannya masing-masing setelah mengucapkan salam; (b) Mematuhi semua ketentuan yang ditetapkan oleh petugas pustaka; (c) Mengambil buku bacaan sesuai dengan mata pelajaran yang sedang dipelajari; (d) Membaca dengan penuh serius dan membuat kesimpulan apa yang telah dibaca; (e) Membalikkan halaman buku haruslah dengan hati-hati dan baik-baik; (f) Setelah membaca buku diletakkan dengan rapi di atas meja bacaan; (g) Menjaga kebersihan ruang dan halaman pustaka selama berada ditempat; dan (h) Keluar dari ruangan dengan teratur, tenang dan mengucap salam; (4) Akhlak di lingkungan labor komputer, meliputi: (a) Memasuki labor bersama guru mata pelajarannya masing-masing setelah mengucapkan salam; (b) Mematuhi, dengan penuh kesadaran,ketentuan yang berlaku; (c) Duduk dengan teratur, tanpa gelisah; (d) Tidak menggunakan peralatan labor tanpa sepengatuhuan guru; (e) Tidak membawa cd, flashdisk, mp3, mp4 dan lainnya; (f) Mengikuti semua intruksi guru dan tidak membuka program lainnya; (g) Menjaga kebersihan ruangan dan halaman selama ada ditempat; dan (h) Keluar dengan tenang dan mengucap salam; (5) Akhlak di Tempat wudhu' dan WC, meliputi: (a) Berjalan dengan tenang ketempat wudhu' dan WC dengan menggunakan sandal bukan sepatu; (b) Menyusun sandal dengan rapi diluar tempat wudhu' dan WC; (c) Memasuki tempat wudhu' dan WC dengan tertib, dimulai dengan do'a dan melangkahkan kaki kiri dengan penuh kesadaran; (d) Tidak memakai air dengan cara mubazir, bermain air dan mengotori air yang ada; (e) Menggunakan gayung, keran dan perelatan yang ada dengan hemat, sopan dan tenang; (f) Membersihkan semua tempat wudhu dan wc setiap mengunankan fasilitas yang ada; (g) Buang air sebelum berwudhu' jika tidak bisa ditahan lagi, dan beristinjak sebersih-bersihnya; (h) Berbaris dengan rapi dan tenang untuk antri dalam melakukan whudu'; (i) Melakukan wudhu' dengan sempurna dan tepat cara; (j) Melaksanakan jadwal piket yang ditetapkan; dan (k) Keluar dari wc dengan kaki kanan dan membaca do'a; (6) Akhlak di Kafetaria dan Mini market, meliputi: (a) Memasuki ruangan dengan tenang dan mengucap salam; (b) Mengambil dan memesan makanan, minuman dan barang dengan tertib, tidak berdesakdesakan dan tidak pula ribut; (c) Berlaku jujur dalam pengambilan barang dan pembayarannya; (d) Meninggalkan ruangan setelah kewajiban dilunasi dan sepengetahuan petugas; (e) Tidak mencicipi atau makan dan minum selama di kafetaria, di mini market, dijalan hingga duduk dengan rapi pada tempat yang telah disediakan; (f) Menjaga kebersihan ruangan dan halaman selama berada ditempat; ( $g$ ) Lingkungan Sekolah; (h) Menjaga kebersihan dan keindahan dan kerapian lingkungan sekolah sepanjang kehadiran ditempat; (i) Melaksanakan jadwal piket dengan sempurna dan benar; (j) Tidak berlari-lari dan ribut; (k) Tidak merusak dan menngganggu taman, pepohonan dan yang ada di 
lingkungan sekolah; (l) Merapikan semua alat-alat dan sususan perlengkapan sekolah sesuai dengan tata ruang yang ditentukan; dan (m) Membaca kalimat-kalimat baik dan mensucikan Allah ketika menikmati pemandangan alam yang ada; dan (7) Akhlak di lingkungan masjid, meliputi: (a) Memasuki masjid dengan tenang setelah mensusun sandal dan berdo'a dengan khusu'; (b) Melangkahkan kaki kanan dan mengambil shaf yang telah ditentukan; (c) Tidak berbicara, gelisah, menoleh kiri, kanan, belakang dan memegang teman selama berada didalam masjid; (d) Melakukan sholat tahiyyatul masjid setiap memasuki masjid sebelum duduk; (e) Mengulang hapalan al Qur'an dan hadits selama menunggu azan dikumandangkan; (f) Melakukan sholat sunat qobliyyah dengan tenang dan tidak tergesa-gesa; (g) Berzikir dan berdo'a dengan khusuk selama menunggu iqomat di kumandangkan; (h) Menyusun shaf dengan segera, tenang, tidak desakdesakan, lurus dan rapi; (i) Selama melaksanakan sholat, gerakan haruslah sempurna, tenang, lembut, tidak malasmalasan, tidak tergesa-gesa dan tidak pula keras; (j) Melaksanakan semua rukun sholat dengan penuh penghayatan dan khusu'; (k) Duduk dengan rapi dan penuh konsentrasi selama berzikir dan berdo'a; (l) Melakukan sholat sunat ba'diyyah dengan tenang dan tidak tergesa-gesa; (m) Keluar masjid tanpa mendorong, memegang dan berdesak-desakan dengan teman; (n) Mendahulukan kaki kiri dan membaca do'a; dan (o) Memasang sandal dengan tertib tanpa menginjak dan merusak sususan sandal yang ada.

Untuk memotivasi anak-anak dalam menerapkan akhlak yang baik, pihak sekolah pada tiap akhir semester memberikan penghargaan terhadap murid-murid yang dinilai berhasil menerapkan tuntunan akhlak di sekolah, dengan nilai rata akhlak 9 atau di lebih. Bentuk penghargaan ditetapkan oleh sekolah. Hal ini merupakan kebanggan tersendiri bagi siswa dan orang tua, sehingga secara tidak langsung, orang tua mempunyai perhatian besar dalam mendidik anak berakhlak mulia di rumah.

Lebih lanjut Pihak sekolah SDIT alBadr, juga menerapkan peraturan amanah kegiatan murid-murid di rumah setelah pulang dari sekolah. Dalam penerapannya pihak sekolah bekerja sama dengan orang tua. Pada beberapa semester, pernah diterapkan pemberian blangko bimbingan akhlak siswa di rumah kepada orang tua, yang harus mereka isi. Namun hal itu tidak berlangsung lama, karena menyibukkan guru, dan terkadang orang tua kurang memperhatikannya. Oleh karena itu penekanan pelaksaan pendidikan akhlak saat ini lebih difokuskan di sekolah di bawah pengawasan guruguru yang telah ditugaskan. Sementara untuk dirumah cukup dengan mengadakan pertemuan intensif dengan orang tua untuk menyatukan visi dan misi bersama untuk membina generasi yang sholeh. Adapun amanah kegiatan siswa di rumah yang ditetapkan sekolah sebagai berikut: (a) Memperhatikan dan atau membaca jadwal kegiatan ketentuan akhlak santri setiap pulang sekolah; (b) Melaksanakan semua kegiatan dengan penuh keikhlasan kepada Allah dan tepat menurut tuntunan Rasulullah SAW; (c) Tidak menonton dan mendengar acara televisi, vcd, radio dan semisalnya kecuali yang baik-baik dan benar; (d) Tidak menggunakan Hp, komputer/ laptop, MP3/ MP4 dan alat teknologi lainnya kecuali untuk yang benar, baik dan sepengetahuan keluarga; (e) Acara yang baik dan benar adalah tidak 
menampilkan aurat laki-laki dan perempuan, tidak menampilkan perempuan dewasa baik berbentuk gambar asli maupun kartun atau virtual, tidak mengandung cerita dan perkataan kotor, bohong, sendagurau berlebihan dan mengumbar hawa nafsu cinta dan sex; (f) Memakai kostum/ pakain yang sesuai dengan keinginan Allah SWT dimana dan kapan saja,yaitu : Lapang (tidak membentuk lekuk tubuh bagi perempuan), tidak transfaran, menutup semua aurat kecuali didepan mahrom ketika didalam rumah; (g) Tidak keluar rumah dan atau melakukan kegiatan kecuali sepengetahuan orang tua atau keluarga; (h) Mengerjakan tugas-tugas sekolah pada malamnya dengan penuh semangat dan bahagia; (i) Selalu memabaca do'a dan mengucapkan salam apabila keluar dan masuk rumah; (j) Malaksanakan sholat, zikir dan do'a dengan khusu' dan dibimbing oleh orang tua serta keluarga; (k) Membantu orang tua dan keluarga dengan penuh ilmu dan sekuat tenaga dan kemampuan; (l) Bersiap-siap ke sekkolah dan memastikan semua pakaian, seragam, peralatan dan perlengkapan sekolah siap pakai dan lengkap; dan (m) Menaiki kenderaan dan atau berjalan dengan hati disertai dengan membaca do'a.

Sedangkan faktor Pendukung keberhasilan implementasi pendidikan akhlak di SDIT al-Badr adalah sebagai berikut: (1) Komitmen yang kuat dari yayasan dalam mewujudkan generasi Islami yang berilmu dan berakhlak mulia.Hal ini tercantum dalam misi SDIT al-Badr, yaitu : Menciptakan lingkungan anak-anak yang cinta ilmu dan menampilkan qudwa almutsla (contoh ideal) dalam proses belajar mengajar; (2) Adanya petunjuk teknis yang jelas untuk pelaksanaan bimbingan akhlak di SDIT al-Badr yang menjadi pedoman para guru, dalam membina dan memberikan penilaian terhadap akhlak murid-murid di SDIT al-Badr baik yang berhubungan dengan dirinya, hubungan dengan Allah, hubungan sesama warga sekolah dan lingkunngan sekolah; (3) Majlis guru merupakan tamatan yayasan al-Badr, yang mempunyai satu visi dan misi yang sama dalam membentuk generasi Islam; dan (4) Kekompakan dan keikhlasan guru (mengharap ridho Allah) untuk mewujudkan generasi Islami yang beraklak mulia, yang telah ditanamakan oleh yayasan kepada seluruh majlis guru. Hal ini tergambar dalam wawancara peneliti dengan salah seorang guru SDIT al-Badr, mengunkapkan "Saya merasa berbahagia sekali dapat ikut serta berdakwah di jalan Allah, dengan mengemban amanah untuk menciptakan generasi Islam yang berakhlak mulia. Bagi saya nilainya sangat berharga bagi kehidupan saya di dunia dan akhirat".

Adapun faktor penghambat, dalam mewujudkan generasi yang berakhlak mulia,yaitu terkadang kurangnya kerjasama orang tua dengan pihak sekolah dalam mewujudkan generasi Islami, seperti ditemukan 3 orang siswa yang bermain di warnet di luar jam sekolah, dalam satu tahun ini, bahkan ada orang tua yang menyediakan untuk anaknya uang untuk ke warnet setiap hari. Namun hal itu dapat dijembatani dengan mengadakan pengajian rutin 2 kali dalam sebulan, 1 kali untuk ibu-ibu dan satu kali untuk bapak, untuk menambah ilmu pengetahuan sekaligus menyatukan visi dan misi untuk mewujudkan generasi yang berakhlak mulia. 


\section{SIMPULAN}

Berdasarkan penelitian yang telah dilaksanakan, dapat diambil beberapa kesimpulan yaitu: (1) SDIT al-Badr Bangkinang merupakan sekolah Dasar Islam terpadu yang mengedepankan pendidikan akhlakul karimah sebagai buah dari ilmu pengetahuan dan bukti keimanan seseorang kepada Allah Swt. Bagi sekolah ini keberhasilan pendidikan dilihat dari seberapa jauh terimplementasinya akhlakul karimah seluruh siswa dalam kehidupan mereka sehari-hari. Oleh karena itu SDIT al-badr menjadikan akhlakul karimah sebagai tujuan utama pendidikan lembaga pendidikan ini; (2) Adapun cara yang ditempuh dalam mewujudkan tujuan ini adalah mengadakan pendidikan tahfizul Quran, bimbingan wuduk, sholat dan zikir, bimbingan, adab dimajlis ilmu, bimbingan akhlak diwaktu jam istirahat, bimbingan adab ke kantin,bimbingan makan dan minum, bimbingan adab dilingkungan sekolah, bimbingan adab pulang, dan bimbingan adab dirumah hingga berangkat ke sekolah; (3) Faktor-faktor yang mendukung keberhasilan sekolah dalam mengimplementasikan pendidikan akhlak adalah komitmen yang kuat dari pihak sekolah, Komitmen yang kuat dari yayasan dalam mewujudkan generasi yang berakhlak mulia, adanya petunjuk teknis yang jelas untuk pelaksanaan bimbingan akhlak di SDIT al-Badr yang menjadi pedoman para guru, dalam membina dan memberikan penilaian terhadap akhlak murid-murid di SDIT al-Badr baik yang berhubungan dengan dirinya, hubungan dengan Allah, hubungan sesama warga sekolah dan lingkunngan sekolah, majlis guru merupakan tamatan yayasan al-Badr, yang mempunyai satu visi dan misi yang sama dalam membentuk generasi Islam, kekompakan dan keikhlasan guru (mengharap ridho Allah) untuk mewujudkan generasi Islami yang beraklak mulia; dan (4) Faktor penghambat dalam mewujudkan generasi yang berakhlak mulia yaitu terkadang kurangnya kerjasama orang tua dengan pihak sekolah dalam mewujudkan generasi Islami, naun hal ini dapat dijembatani dengan diadakannya pertemuan rutin orang tua dan pihak sekolah 2 kali dalam sebulan untuk menyatukan visi dan misi dalam mewujudkan anak sholeh.

Adapun saran kepada pihak sekolah agar terus mengupayakan berbagai program untuk mewujudkan generasi Islami yang berakhlak mulia, dan lebih menjalin hubungan yang baik dengan para wali murid, dengan terus mengadakan pertemuan, dan membuat suatu buku pemantau prilaku anak di rumah mereka, sehingga pendidikan di sekolah berlanjut dengan pendidikan di lingkungan rumah. Disamping itu, keberhasilan pendidikan akhlak harus dibarengi dengan peningkatan kemampuan di bidang akademi yang baik juga. Oleh karena itu pihak sekolah harus harus memperhatikan hal tersebut, sehingga akan terwujudlah generasi Islam yang berintegritas; berilmu, berprestasi dan beraklak mulia.

Kepada Pemerintah Kabupaten Kampar, agar menjadikan pola pendidikan akhlak di SDIT al-Badr, dapat dijadikan contoh dalam mewujudkan generasi yang berilmu dan berakhlak mulia, dan selanjutnya dapat dijadikan acuan pada sekolah-sekolah dasar lainnya di Kabupaten Kampar.

\section{DAFTAR PUSTAKA}

Al-Abrasyi, Muhammad 'Athiyyah. 2003. Prinsip-Prinsip Dasar Pendidikan. Bandung: Pustaka Setia. 
Al-Ghazali, Imam. t.t. Ihya' Ulumuddin Juz III. Beirut: Dar Ihya al-Kutub al-Ilmiyah.

1989. Pedoman Amaliah Ibadat. Semarang: CV.Wicaksana

Ali, M. Daud. 2000. Pendidikan Agama Islam. Jakarta : PT. Raja Grafindo Persada.

Amin, Ahmad. 1975. Etika (Ilmu Akhlak), terj. K.H. Farid Ma'ruf. Jakarta: Bulan Bintang.

Arifin, M., 2000. Filsafat Pendidikan Islam. Jakarta : Bumi Aksara.

AR, Zahruddin dan Sinaga, Hasanuddin. 2004. Pengantar Studi Akhlak. Jakarta: PT. Raja Grafindo Persada.

Daulay, Haidar Putra. 2004. Pendidikan Islam Dalam Sistem Pendidikan Nasional di Indonesia. Jakarta: Kencana.

Departemen Agama Republik Indonesia. 1994. Al-Qur'an dan Terjemahnya. Semarang: PT. Kumudasmoro Grafindo.

Departemen Pendidikan dan Kebudayaan. 1994. Kamus Besar Bahasa Indonesia. Jakarta: Balai Pustaka.

Djatnika, Rahmat. 1994. Sistem Ethika Islami (Akhlak Mulia). Jakarta: Balai Pustaka.

Djatnika, Rachmat. 1996. Sistem Etika Islan (Akhlak Mulia). Jakarta: Pustaka Panjimas.

Donald, Frederic J. Mc., 1959. Educational Psychology. San Francisco: Wadsworth Publishing Company Inc.

Hambal, Al Imam Ahmad bin. t.t. Musnad Juz II. Beirut: Darul Kutub al Ilmiyah.

Hadi, Sutrisno. 1987. Metodologi Research II. Yogyakarta: Andi Offset.

Hasan, M. Ali. 1988. Tuntunan Akhlak. Jakarta: Bulan Bintang.
Henry, Nelson B., 1962. Philosophies of Education. USA: The University.

Hurlock, Elizabeth B., 1978. Child Development, Edisi IV. New York: Mc. Grow Hill.

Istanto, Habibah. 2007. Metode Pengembangan anak Pra Sekolah. Yogyakarta: FIP UNY.

Jalaluddin. 2001. Teologi Pendidikan. Jakarta: PT. Raja Grafindo Persada.

Marimba, Ahmad D., 1989. Pengantar Filsafat Pendidikan Islam. Bandung: Al-Ma'arif.

Mutahhari, Murtadha. 1997. Manusia dan Alam Semesta: Konsepsi Islam Tentang Jagad Raya. Jakarta: Lentera.

Nashir, Haedar. 2007. Leptop Dewan. Yogyakarta: Kedaulatan Rakyat.

Nata, Abudin. 1997. Akhlak Tasawuf. Jakarta: PT. Raja Grafindo Persada.

Miles dan hberman. 1992. Analisis data Kualitatif, terjem., Tjetjep Rohendi. Jakarta:UI Press.

Quasem, Muhammad Abul dan Kamil, Ahmad. 1975. Etika Al-Ghazali: Etika Majemuk Di Dalam Islam. penerjemah J. Muhyidin. Bandung: PT. Penerbit Pustaka.

Raharjo, Setya. 2005. Pendidikan Multi Kultural. Yogyakarta: FIP UNY.

Raharjo, et. al., 1999. Pemikiran Pendidikan Islam, Kajian Tokoh Klasik dan Kontemporer, Fakultas Tarbiyah IAIN Walisongo. Yogyakarta: Pustaka Pelajar.

Santhut, Khatib Ahmad. 1998. Daur alBait fi Tarbiyah ath-Thifl alMuslim, terj. Ibnu Burdah, "Menumbuhkan Sikap Sosial, Moral dan Spiritual Anak dalam Keluarga Muslim, Yogyakarta: Mitra Pustaka.

Sudjana, Nana. 1991. Pembinaan dan Pengembangan Kurikulum di Sekolah. Bandung: Sinar Baru. 
Sukmadinata. 2007. Metode Penelitian Pendidikan. Bandung : PT. Remaja Rosda Karya.

Suwito. 2004. Filsafat Pendidikan Akhlak Ibnu Maskawaih. Yogyakarta: Belukar.

Suyanto, Slamet. 2005. Konsep Dasar Pendidikan Anak Usia Dini. Jakarta: Depdikbud, Dirjendikti, Direktorat Pembinaan Tenaga Pendidikan dan Perguruan Tinggi.
Thoha, Chabib dan Zuhri, Saifudin. 1999. Metodologi Pengajaran Agama. Yogyakarta: Pustaka Pelajar Fakultas Tarbiyah.

Umari, Barnawy. 1984. Materi Akhlak. Sala : Ramadhani.

Yaljan, Miqdad. 2003. Kecerdasan Moral: Aspek Pendidikan Yang Terlupakan. Yogyakarta: Talenta.

Zuhairini, et. al. 1993. Metodologi Pendidikan Agama. Bandung: Ramadhani. 